\title{
The effect of COVID-19 on the economy: Evidence from an early adopter of localized lockdowns
}

\author{
Kenzo Asahi ${ }^{1,2}$, Eduardo \\ A Undurraga ${ }^{1,3,4,5}$, Rodrigo \\ Valdés ${ }^{1,5}$, Rodrigo Wagner ${ }^{6,7}$ \\ ${ }^{1}$ Escuela de Gobierno, Pontificia Uni- \\ versidad Católica de Chile, Santiago, \\ Región Metropolitana, Chile \\ ${ }^{2}$ Centre for Sustainable Urban Devel- \\ opment (CEDEUS), Chile \\ ${ }^{3}$ Millennium Nucleus for the Study \\ of the Life Course and Vulnerability \\ (MLIV), Santiago, Chile \\ ${ }^{4}$ Millennium Initiative for Collabora- \\ tive Research in Bacterial Resistance \\ (MICROB-R), Santiago, Chile \\ ${ }^{5}$ Research Center for Integrated Di- \\ saster Risk Management (CIGIDEN), \\ Santiago, Chile \\ ${ }^{6}$ Business School, Universidad Adolfo \\ Ibáñez, Santiago, Chile \\ ${ }^{7}$ Growth Lab, Center for International \\ Development, Harvard, Cambridge, \\ Massachusetts, USA
}

\begin{abstract}
Background Governments worldwide have implemented large-scale non-pharmaceutical interventions, such as social distancing or school closures, to prevent and control the growth of the COVID-19 pandemic. These strategies, implemented with varying stringency, have imposed substantial social and economic costs to society. As some countries begin to reopen and ease mobility restrictions, lockdowns in smaller geographic areas are increasingly considered an attractive policy intervention to mitigate societal costs while controlling epidemic growth. Nevertheless, there is a lack of empirical evidence to support these decisions.

Methods Drawing from a rich data set of localized lockdowns in Chile, we used econometric methods to measure the reduction in local economic activity from lockdowns when applied to smaller or larger geographical areas. We measured economic activity by tax collection at the municipality-level.
\end{abstract}

Results Our results show that lockdowns were associated with a 10\%-15\% drop in local economic activity, which is twice the reduction in local economic activity suffered by municipalities that were not under lockdown. A three-to-four-month lockdown had a similar effect on economic activity than a year of the 2009 great recession. We found costs are proportional to the population under lockdown, without differences when lockdowns were measured at the municipality or citywide levels.

Conclusions Our findings suggest that localized lockdowns have a large effect on local economic activity, but these effects are proportional to the population under lockdown. Our results suggest that epidemiological criteria should guide decisions about the optimal size of lockdown areas since the proportional impact of lockdowns on the economy seems to be unchanged by scale.

\section{Correspondence to:}

Eduardo A. Undurraga

Escuela de Gobierno

Pontificia Universidad Católica de

Chile

Vicuña Mackenna 4860

Macul CP 7820436

Región Metropolitana

Chile

eundurra@uc.cl
Despite the historic approvals in the United Kingdom and the United States of a COVID-19 vaccine tested in a large clinical trial [1,2], non-pharmaceutical interventions are still the main strategies to control viral transmission in the COVID-19 pandemic [3-6]. These interventions range from individual-level recommendations, such as the use of facemasks or frequent hand-washing, to large-scale regulations and policies, such as large-scale lockdowns and non-essential business closures $[7,8]$. Several countries have achieved some control over the COVID-19 based on a combination of non-pharmaceutical interventions and high levels of testing and isolation of infected people [9-15]. However, several countries are going through the second wave of infections, and there is a substantial risk of a resurgence of the epidem- 
ic elsewhere [16-19]. Understanding these interventions' impacts is critical because they will most likely continue until an effective vaccine becomes available for a substantial proportion of the population [20]. There is still limited empirical evidence of the effects of interventions to prevent viral transmission [3,21]. Most intervention's impact has been estimated using mathematical models [20,22-26]. The COVID-19 pandemic has already imposed an enormous global burden, with about 72 million cases and one million deaths reported so far, and substantial social and economic costs from epidemic control measures [27-33].

As countries have begun to reopen and ease mobility restrictions, localized lockdowns are increasingly considered a critical element of a non-pharmaceutical toolkit to control COVID-19 resurgence [9,10,23,34,35]. In contrast to nation-wide lockdowns, localized lockdowns are implemented over a limited geographical area, ranging from a neighbourhood to a city, including suburbs, districts, or towns. Localized lockdowns may be appealing to policy-makers because, in principle, they would allow countries to reopen and reclose specific jurisdictions based on local virus transmission dynamics. Large-scale lockdowns are unsustainable because of the high costs they impose on the population [15]. Thus, compared to large-scale interventions, localized lockdowns may control transmission hotspots while mitigating some social and economic costs. Policy-makers need to make decisions about COVID-19 control strategies, considering their epidemiological, social, and economic effects.

Epidemiological evidence is one of several criteria for decision-making regarding non-pharmaceutical interventions. For example, a policy-maker would want to understand if costs of foregone economic activity are proportional to the population under lockdown or whether per-person costs are mitigated or amplified when lockdowns are implemented at different administrative levels (eg, municipality, city, state, country). On the one hand, demand spill overs would suggest that people in a municipality could buy in stores of the neighbouring municipality and, through substitution, limit the economic fallout in the city as a whole. On the other hand, the fall in economic activity could be more than proportional if a lockdown affects supply chains, such as when workers cannot work in a neighbouring municipality because of mobility restrictions in their municipality of residence. The answer to this question is mostly empirical, as there are good arguments to both sides. However, there is limited and non-conclusive evidence on the economic costs of non-pharmaceutical interventions. Researchers in the United States have examined how non-pharmaceutical interventions have impacted unemployment insurance, employment, or store client traffic $[28,30,36-40]$. Some research suggests that lockdowns explain a small share of the total economic activity decline $[28,36-38]$. Others $[30,39,40]$ have found that lockdowns play a relevant role in explaining the drop in economic activity. We test these effects in a setting where localized lockdowns were implemented intermittently at different administrative levels, thus allowing us to identify the impact of localized lockdowns on economic activity.

The World Health Organization declared South America as the new epicentre of COVID-19 on May 22, 2020 [41]. Despite implementing several epidemic control strategies early in the pandemic, including travel restrictions, school closures, and mandatory lockdowns, the pandemic has imposed a massive toll on the region. As of December 13, South America has reported more than 360 thousand deaths [42]. Adjusted by population, Argentina, Colombia, Chile, Brazil, and Peru are among the countries with the most reported COVID-19 infections and deaths globally. The epidemic is far from controlled [42-44]. While mostly failing to stop viral spread $[43,45]$, Latin America is now facing the social and economic costs of large-scale non-pharmaceutical interventions.

Since the beginning of the epidemic, Chile has implemented localized lockdowns at the municipality level, the smallest administrative subdivision in the country, at various points in time (Figure 1). The government roughly defined the criteria for implementing localized lockdowns as a function of disease burden, growth in transmission, and health care capacity but did not define specific thresholds [46]. Epidemiological evidence suggests that localized lockdowns reduce epidemic growth [47], but their effectiveness is heavily affected by their duration, spill overs from neighbouring communities, and socioeconomic status of the population affected [48,49]. Localized lockdowns have helped contain the transmission of the virus in isolated areas. Still, they cannot control the epidemic in highly interdependent areas, such as municipalities within a metropolitan area [21].

Drawing on a rich integrated data set, including value-added tax (VAT) revenues, population data, and daily incidence of laboratory-confirmed COVID-19 cases, we use econometric methods to empirically estimate the economic costs of these localized lockdowns in Chile. We hope these results will help inform policy implementation decisions in the context of the COVID-19 pandemic. 


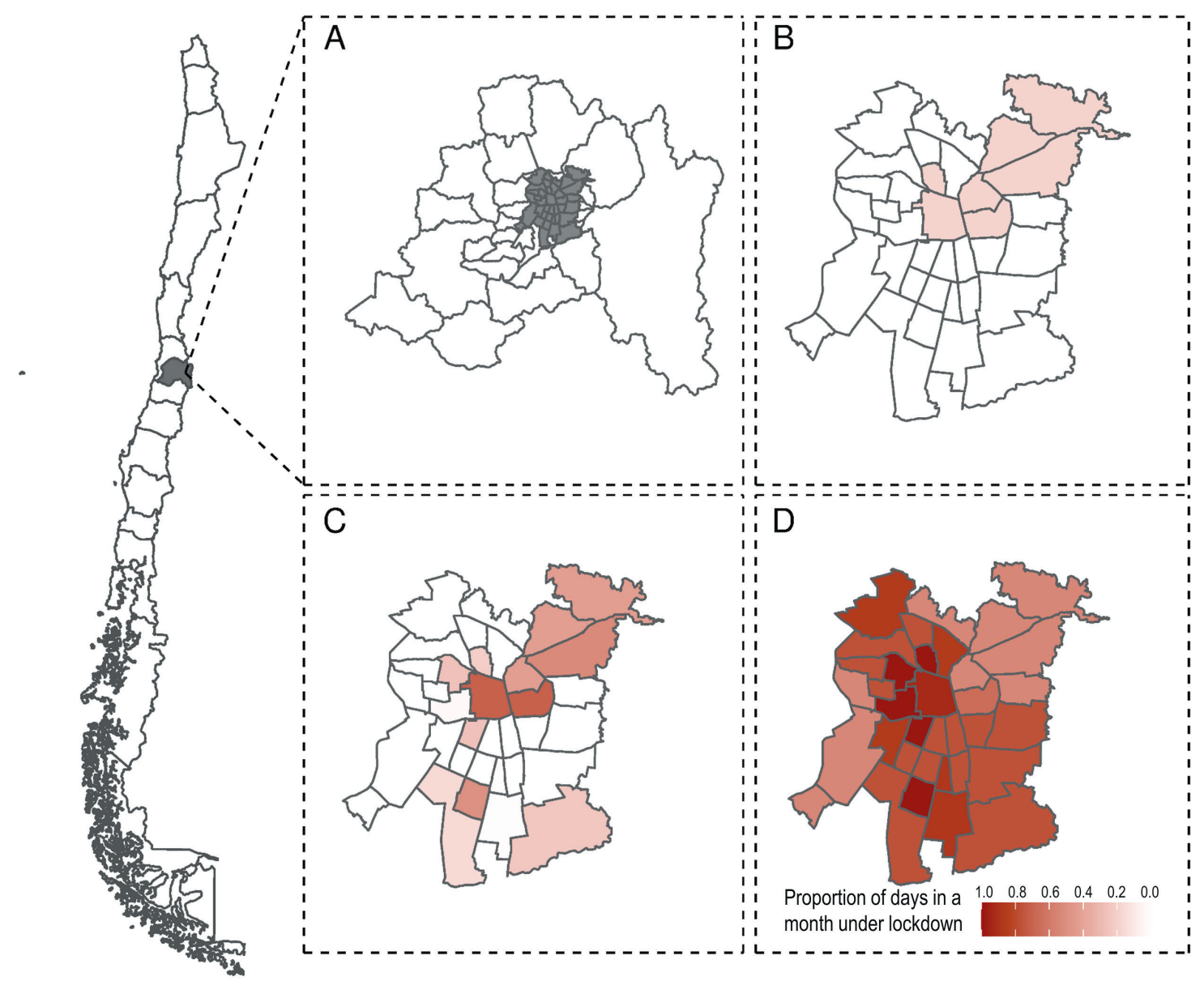

Figure 1. Illustration of localized lockdowns at the municipality level, Greater Santiago, Chile, March-May 2020. To control COVID-19 growth, the Ministry of Health implemented localized lockdowns at the country's municipality level, the smallest administrative subdivision. The figure illustrates these lockdowns implemented in Greater Santiago (A in grey) during different months: March (B), April (C), and May (D), where the colour scale represents the proportion of days in a month under lockdown for each municipality.

\section{METHODS}

\section{Data}

Value-added tax (VAT) applies to all goods with a flat rate of 19\% in Chile. VAT is collected and paid monthly to the Chilean tax authority (Servicio de Impuestos Internos). Our data includes VAT at the municipality level, by all firms registered in the Chilean tax authority, for 2018-2020. VAT collection has a tight one-to-one relationship with GDP; it is, therefore, a good proxy for economic activity. Both variables cointegrate in time series and panel analysis; error correction models suggest that half-life deviations vanish in less than a year [50].

We used Chile's 2017 National Census [51] to estimate each municipality's population and epidemiological surveillance records for COVID-19 from Chile's Ministry of Health [46,52]. We obtained mobility data from the Data Science Institute at Universidad del Desarrollo [53,54]. Mobility data correspond to Chile's largest telecommunications operator. Data on COVID-19, mobility, and population are publicly available on institutional websites [51-53]. The data on VAT used for this study are available from the corresponding author upon reasonable request and with permission of the Chilean tax authority.

\section{Analysis}

We used the collection of the VAT as our dependent variable. Our lockdown variable corresponds to the proportion of days that a municipality $i$ is in lockdown in a given month $t$ :

$$
\text { Lockdown }_{i, t}=\sum \text { quarantine days } / \text { Total month's days }{ }_{t}
$$


We limited our analysis to the 170 municipalities with above-median total VAT in 2018, excluding mostly small and rural municipalities. This preferred sample of municipalities includes 97\% of Chile's 2018 VAT and $89 \%$ of the population (Figure 2). Our sample also excluded the three municipalities that concentrate large-company headquarters (Santiago, Las Condes, and Providencia), such as banks and mining companies, because VAT data in these municipalities do not reflect local economic activity.

a

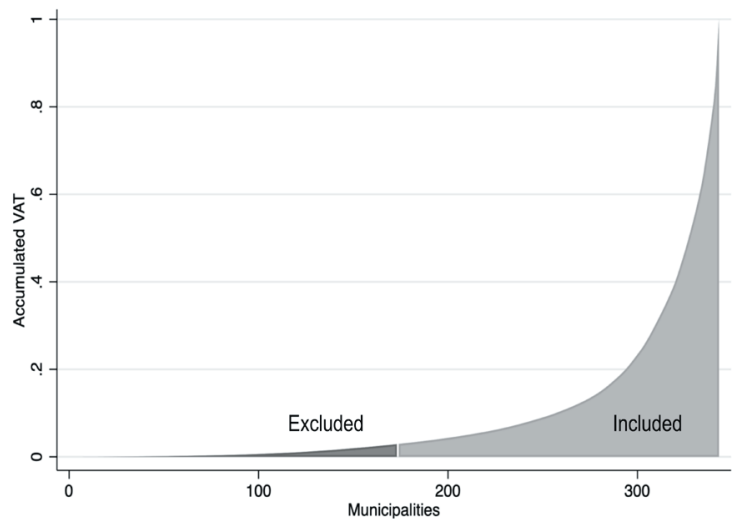

b

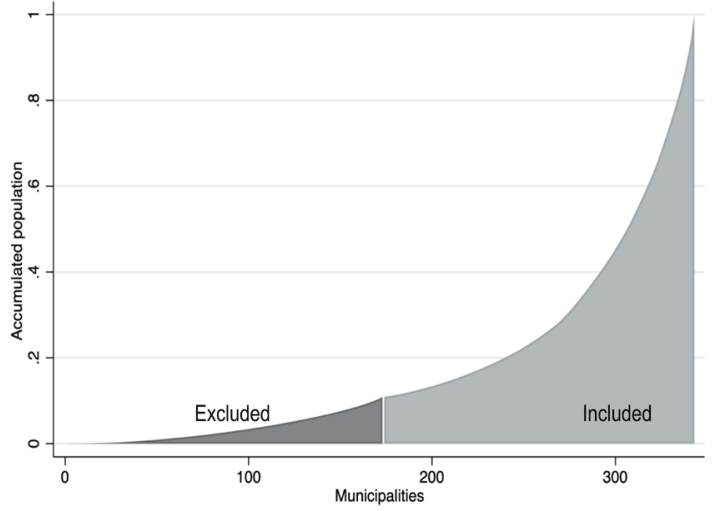

Figure 2. VAT and population cumulative distribution across all municipalities. Panel (a) shows the proportion of total 2018 VAT considered in our baseline sample. We sorted the 343 municipalities in our data set in ascending order by 2018 VAT. We calculated the accumulated tax from the one with the lowest to the highest VAT level. Municipalities not considered in our baseline sample account for 2.9\% of the total 2018 VAT (darker area), while the remaining 97.1\% (lighter area) is in our preferred sample. Panel (b) shows the proportion of the total population, according to the 2017 Census within our preferred sample. In this case, we sorted the municipalities in ascending order. We then calculated the total population's accumulated percentage not considered in our sample, which is $10.9 \%$ (darker area). Hence, the remaining 89.1\% (lighter area) is in our sample.

Our main empirical specification is a two-way fixed-effects model:

$$
\Delta \% \mathrm{VAT}_{\mathrm{it}}=\beta+\beta_{1} \text { lockdown }_{\mathrm{it}}+\beta_{2} \mathrm{X}_{\mathrm{it}}+\gamma_{\mathrm{i}}+\delta_{\mathrm{t}}+\varepsilon_{\mathrm{it}}
$$

where $\triangle \% V A T_{i t}$ corresponds to the percent variation of total VAT collected in municipality $i$ at month $t$ in 2020 relative to the same month in 2019. lockdown it is our variable of interest and represents the proportion of days in a month that a municipality was under lockdown. $\gamma_{i}$ and $\delta_{t}$ correspond to municipality and time fixed-effects, respectively. A distinctive feature of our setting is that lockdown ${ }_{i t}$ effectively changes by municipality and month, providing a variation that allows for a plausible estimate of effects (Figure 1). We controlled for threat or risk perception [55] and social distance by adding new monthly COVID-19 cases or new monthly COVID-19 deaths in the municipality $i$ at time $t$ (variable $\mathrm{X}_{\mathrm{it}}$ ) as covariates. For instance, people may not open their businesses or spend in the local economy because they fear COVID-19 contagion, independent of whether their municipality is under lockdown or not.

Similar to virus transmission spill overs, the economic effects of localized lockdowns within a city or in a conurbation may differ from more relatively isolated municipalities with no neighbouring urban areas ("standalone" municipalities). To examine whether the impact of lockdowns on economic activity is heterogeneous depending on whether municipalities belong to a conurbation or are a standalone municipality, we used the following regression specification:

$$
\Delta \% \mathrm{VAT}_{\mathrm{it}}=\beta_{0}+\beta_{1} \text { lockdown }_{\mathrm{it}}+\beta_{2} \text { standalone }_{\mathrm{i}}+\beta_{3} \text { standalone }_{\mathrm{i}} \times \text { lockdown }_{\mathrm{it}}+\gamma_{\mathrm{i}}+\delta_{\mathrm{t}}+\varepsilon_{\mathrm{it}}
$$

where standalone takes a value of one for standalone municipalities and zero otherwise.

The economic effects of localized lockdowns may differ depending on the area under lockdown - for example, at the municipality or conurbation level. To examine this question, we also ran our analysis comparing all municipalities within a conurbation with standalone municipalities. We weighted the number of days in lockdown in month $t$ of each municipality $i$ belonging to the conurbation $c$ according to the total 2018 VAT:

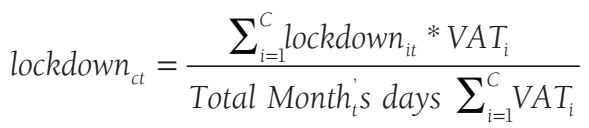


We estimated deaths and COVID-19 cases as a weighted average of deaths in municipalities within the conurbation, using the municipality's population as the weight. Hence, the equation describing per capita COVID deaths in each conurbation is as follows:

$$
\text { Percapita COVID deaths } s_{c t}=\frac{\sum_{i=1}^{C} \text { COVID death }_{i t}}{\sum_{i=1}^{C} \text { Population }_{i}}
$$

Last, we investigate how mobility at the municipality-level affects economic activity. We used a mobility index based on cell phone data. The index was calculated from anonymized aggregate records of mobile telephones in Santiago, which describe trips within and between municipalities. Data are not based on the mobile phone's exact location but on the antenna to which the phones were connected. Each trip is defined by the person's mobile phone moving between antennas [53,54].

\section{RESULTS}

\section{Descriptive statistics}

Table 1 shows the main descriptive statistics of our sample. Figure 3 shows the longitudinal effects of lockdown. As a benchmark, municipalities without a localized lockdown saw a 15\% drop in VAT collection in April-May 2020 compared to the same months of 2019. By contrast, municipalities with lockdown suffered a more substantial decline of 25\%-30\% in VAT collection, again measured vis-à-vis the previous year. Figure 4 shows a cross-section, considering month and municipality fixed-effects. The figure shows a clear relationship between the extent of lockdowns and the decline in VAT.

Table 1. Descriptive statistics related to localized lockdowns in Chilean municipalities, March-May 2020.

\begin{tabular}{|c|c|c|c|c|}
\hline & $\mathbf{N}$ & MUNICIPALITIES & MEAN & SD \\
\hline \multicolumn{5}{|c|}{ VAT log growth rate periods, compared to the same month in the previous year: } \\
\hline Before the outbreak: January-February 2020 & 340 & 170 & 0.083 & 0.423 \\
\hline During the pandemic: March-May 2020 & 510 & 170 & -0.139 & 0.319 \\
\hline \multicolumn{5}{|l|}{ Lockdown (\% of days): } \\
\hline March-May 2020 & 510 & 170 & 0.082 & 0.227 \\
\hline Conditional on one day at least & 153 & 51 & 0.273 & 0.348 \\
\hline \multicolumn{5}{|l|}{ Mobility index (mobile phones): } \\
\hline Before COVID-19 (March 1-15) & 170 & 170 & 8.03 & 3.24 \\
\hline During COVID-19 (March 16-May 31) & 510 & 170 & 6.12 & 2.57 \\
\hline \multicolumn{5}{|l|}{ New COVID-19 deaths per million population: } \\
\hline March 2020 & 170 & 170 & 2.13 & 6.61 \\
\hline April 2020 & 170 & 170 & 20.32 & 27.90 \\
\hline May 2020 & 170 & 170 & 108.95 & 147.54 \\
\hline \multicolumn{5}{|c|}{ New COVID-19 incidence per million population: } \\
\hline March 2020 & 168 & 168 & 59.54 & 119.57 \\
\hline April 2020 & 170 & 170 & 633.38 & 729.48 \\
\hline May 2020 & 170 & 170 & 3160.5 & 4319.0 \\
\hline
\end{tabular}

SD - standard deviation, VAT - value-added tax

*The VAT year-over-year growth rate is calculated as the difference in logarithms of VAT for each month and each municipality relative to 12 months before. As such, a number like 0.08 is approximately an $8 \%$ drop vis-à-vis the previous year. In the VAT growth rate for "March-May 2020," we include the growth rate for each month-municipality in that period. We consider that the disruption of the COVID-19 pandemic on mobility occurred on March 16 because the government closed all schools on that date [46]

\section{Multivariate analysis}

\section{Municipality level}

Table 2 presents our baseline results for the effect of lockdowns on economic activity. Table 2, column (1) shows that one month of lockdown decreases monthly VAT around $12.5 \%$ ( $\beta=-0.125 ; 95 \%$ confidence interval $(\mathrm{CI})=-0.220,-0.031 ; P=0.009)$. The coefficient or the effect of lockdowns has about the same magnitude when restricting the sample to municipalities with at least $50 \%$ of the urban population (Table 2 , column 2; $\beta=-0.132 ; 95 \% C I=-0.228,-0.035 ; P=0.008$ ). Table 2 , column (3) shows the results for municipalities with less than $50 \%$ of rural population and excluding observations from Greater Santiago. To 


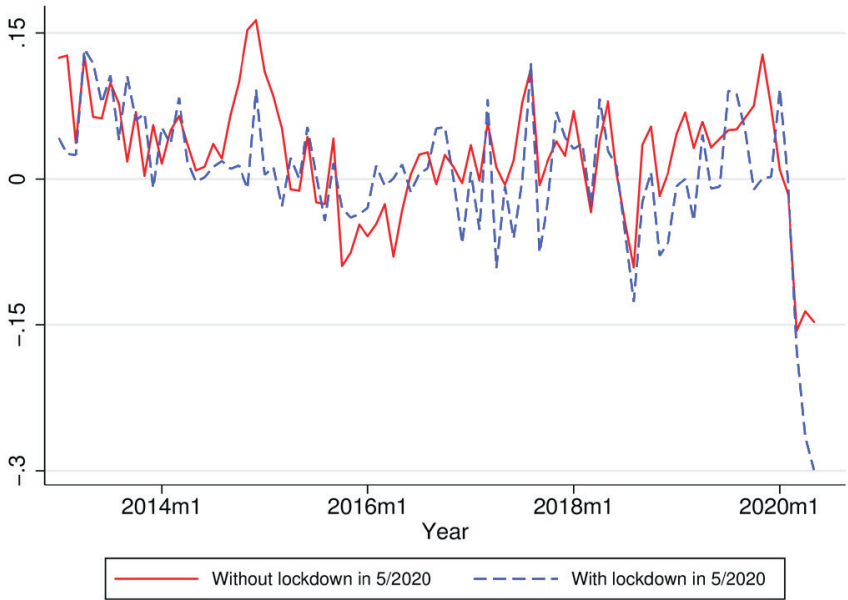

Figure 3. Median of the real value-added-tax (VAT) year-on-year growth rates. The graphs show the median of VAT growth rates for municipalities under lockdown in May 2020 (blue) and municipalities that were not under lockdown (red). The median of the value-added-tax (VAT) growth rate in May 2020 for municipalities with and without lockdown is 2.67 and 5.37 standard deviations lower than the mean of such medians in the 2006-2019 period. The sample of municipalities includes municipalities over the 50th percentile of the total 2018 VAT

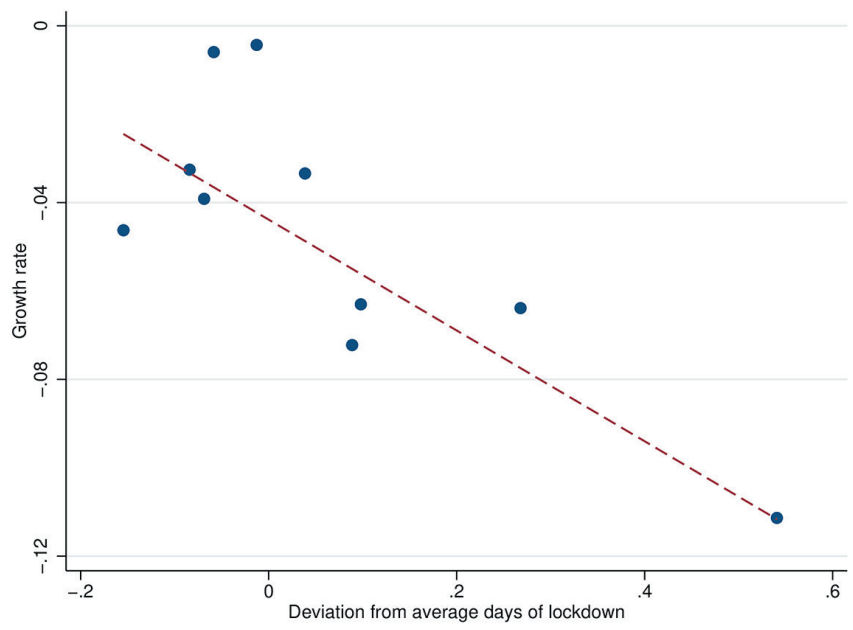

Figure 4. Effect of lockdown on value-added-tax (VAT) collection for January 2020 through May 2020, controlling for month and municipality fixed effects. The results show the association between lockdown on VAT collection for January 2020 through May 2020, controlling for month and municipality fixed effects. We group the municipalities of our baseline sample into equal-sized bins according to days of lockdown between January 2020 and May 2020. Each dot represents the mean VAT collection growth rate (y-axis) and the mean deviation from lockdown as a percentage of a month (x-axis) within each bin. Each bin has 17 municipalities. The red dashed line represents the population regression line.

closely interdependent neighbouring areas. For the analysis, we collapsed municipalities into conurbations. Our sample now had eighteen conurbations and seventeen standalone municipalities in our baseline sample.

Table 3, column (1), shows a statistically significant decline in monthly VAT collection of around 18\% $(\beta=-0.184 ; 95 \% C I=-0.360,-0.009 ; P=0.042)$. Because Greater Santiago had the largest number of municipalities with lockdown, we dropped Greater Santiago from the sample to test our results (Table 3, column 2). The effect's magnitude remained but was significant only at the $90 \%$ level $(\beta=-0.188 ; 95 \% \mathrm{CI}=-0.382$, 0.051; $P=0.056$ ). In Table 3, column 3, we examined whether there was a differential effect for standalone

assess our estimates' robustness, we excluded municipalities in Greater Santiago, the conurbation in Chile with the highest proportion of municipalities in lockdown between March and May 2020. We found that VAT decreases 16 percentage points for each month of lockdown, but the coefficient is only significant at the $90 \%$ level $(\beta=-0.162 ; 95 \%$ $\mathrm{CI}=-0.350,0.0268 ; P=0.093)$.

We then limited our sample to urban municipalities $(\mathrm{n}=72)$ that are part of a conurbation (Table 2, column 4). One month of lockdown results in a monthly VAT decrease of 16 percentage points $(\beta=-0.161 ; 95 \% \mathrm{CI}=-0.287,-0.034$; $P=0.013)$. We found similar results when excluding Greater Santiago (Table 2, column 5; $\beta=-0.153 ; 95 \% \mathrm{CI}=-0.410$, $0.103 ; P=0.240)$

We added an interaction term to examine whether lockdowns had a different effect on VAT in municipalities that are part of a conurbation or in standalone municipalities. The results in Table 2, column (6) show a 23\% decline in monthly VAT collection due to a one-month lockdown $(\beta=-0.230 ; 95 \% C I=-0.345,-0.115 ; P<0.001)$. However, we did not find evidence of a differential effect for standalone municipalities relative to municipalities in conurbations.

Last, we examined whether perceived threat or risk from new COVID-19 deaths or new cases could be an omitted variable bias in the effect of local lockdowns on economic activity. Table 2, Column (7) includes the municipality's one-month per-capita COVID deaths per 100000 population as control. The lockdown effect is roughly the same as in column 1 ( $\beta=-0.125 ; 95 \% \mathrm{CI}=-0.265,0.013 ; P=0.077)$. Controlling for COVID-19 monthly incidence per 100000 population Table 2, Column (8) shows that one month of lockdown results in a thirteen percent decrease in VAT collection $(\beta=-0.135 ; 95 \% \mathrm{CI}=-0.237,-0.033 ; P=0.010)$. Results are robust to using one-month lagged COVID-19 deaths and cases.

Overall, Table 2 suggests that one month of lockdown would reduce economic activity by $10 \%-15 \%$, robust to several model specifications. Notably, the effect size is not affected when controlling for COVID-19 deaths or case incidence, suggesting that this sample's lockdown effect goes over and above the impact of perceived threat or risk of contagion.

\section{Conurbations and standalone municipalities}

Next, we examined the effects of lockdowns on VAT when analysed for conurbations or standalone municipalities (Table 3). The objective was to test whether the effects of lockdowns were different when there were no spill overs from
the analysis, we collapsed municipalities into conurbations. 
Table 2. Regressions results for the effect of one month localized lockdown on total VAT collection, estimated with two-way fixed effects at the municipality level, January-May 2020

\begin{tabular}{|c|c|c|c|c|c|c|c|c|}
\hline \multirow[t]{2}{*}{$\begin{array}{l}\text { DEPENDENT VARIABLE: VAT } \\
\text { GROWTH }\end{array}$} & BASELINE & $\begin{array}{l}\text { EXCLUDING } \\
\text { RURAL UNITS }\end{array}$ & $\begin{array}{l}\text { EXCLUDING } \\
\text { GREATER } \\
\text { SANTIAGO }\end{array}$ & CONURBATIONS & $\begin{array}{l}\text { CONURBATIONS } \\
\text { EXCLUDING GREATER } \\
\text { SANTIAGO }\end{array}$ & $\begin{array}{l}\text { CONURBATIONS } \\
\text { AND STANDALONE } \\
\text { MUNICIPALITIES }\end{array}$ & $\begin{array}{l}\text { AS IN (1) } \\
\text { CONTROLLING } \\
\text { FOR DEATHS }\end{array}$ & $\begin{array}{l}\text { AS IN (1) } \\
\text { CONTROLLING } \\
\text { FOR CASES }\end{array}$ \\
\hline & (1) & (2) & (3) & (4) & $(5)$ & (6) & (7) & (8) \\
\hline \multirow[t]{2}{*}{ Lockdown } & $-0.125 \S$ & $-0.132 \S$ & $-0.162 \dagger$ & $-0.161 \ddagger$ & -0.153 & -0.2308 & $-0.125 \dagger$ & $-0.135 \S$ \\
\hline & $(0.048)$ & $(0.049)$ & $(0.096)$ & $(0.064)$ & $(0.130)$ & $(0.059)$ & $(0.071)$ & $(0.052)$ \\
\hline \multirow[t]{2}{*}{ Standalone $\times$ lockdown } & & & & & & -0.059 & & \\
\hline & & & & & & $(0.104)$ & & \\
\hline \multirow[t]{2}{*}{ Standalone } & & & & & & -0.005 & & \\
\hline & & & & & & $(0.038)$ & & \\
\hline \multirow[t]{2}{*}{ New deaths per 100000} & & & & & & & 0.00004 & \\
\hline & & & & & & & $(0.002)$ & \\
\hline \multirow[t]{2}{*}{ New log cases per 100000} & & & & & & & & 0.002 \\
\hline & & & & & & & & $(0.005)$ \\
\hline Observations & 850 & 785 & 570 & 360 & 195 & 455 & 850 & 850 \\
\hline Adjusted $\mathrm{R}^{2}$ & 0.352 & 0.369 & 0.356 & 0.352 & 0.278 & 0.171 & 0.351 & 0.351 \\
\hline Time effect & YES & YES & YES & YES & YES & YES & YES & YES \\
\hline Municipalities & 170 & 157 & 114 & 72 & 39 & 91 & 170 & 170 \\
\hline
\end{tabular}

VAT - value-added tax 170

*All specifications have both geography and time fixed effects. Robust standard errors in parenthesis. Column (1) shows regression results for the baseline sample (ie, municipalities over the $50^{\text {th }}$ percentile of total 2018 VAT). Column (2) excludes units, with over fifty percent of the rural population. Column (3) is the same as (2) but excluding municipalities in Greater Santiago, the capital. Columns (4) includes only municipalities that are part of a large conurbation. Column (5) is the same as column (4), excluding municipalities in Greater Santiago. Column (6) includes municipalities that are part of large conurbations and standalone municipalities (Angol, Antofagasta, Arica, Aysén, Calama, Castro, Chañaral, Colina, Copiapó, Curicó, Osorno, Ovalle, Puerto Montt, Puerto Natales, Punta Arenas, Valdivia, and Vallenar). Columns (7) and (8) consider the baseline sample and controls for contemporaneous COVID-19 new deaths and lagged incidence per 100000 population, respectively, at the municipality level.

$\uparrow P<0.10$.

$\$ P<0.05$.

$\S P<0.01$

Table 3. Regressions results for the effect of one month localized lockdown on total VAT collection, estimated with two-way fixed effects for conurbations and standalone municipalities, January-May 2020

\begin{tabular}{|c|c|c|c|c|c|}
\hline DEPENDENT VARIABLE: VAT GROWTH & $\begin{array}{l}\text { ALL CONURBATIONS AND } \\
\text { STANDALONE MUNICIPALITIES }\end{array}$ & $\begin{array}{l}\text { EXCLUDING GREATER } \\
\text { SANTIAGO }\end{array}$ & $\begin{array}{c}\text { AS IN (1) INTERACTING } \\
\text { LOCKDOWN \& STANDALONE }\end{array}$ & $\begin{array}{l}\text { AS IN (1) WITH PER } \\
\text { CAPITA DEATHS }\end{array}$ & $\begin{array}{l}\text { AS IN (1) WITH LOG } \\
\text { PER CAPITA INCIDENCE }\end{array}$ \\
\hline & (1) & $(2)$ & (3) & (4) & (5) \\
\hline \multirow[t]{2}{*}{ Lockdown } & $-0.184 \ddagger$ & $-0.188 \dagger$ & -0.2438 & -0.126 & -0.157 \\
\hline & $(0.089)$ & $(0.020)$ & $(0.064)$ & $(0.106)$ & $(0.116)$ \\
\hline \multirow[t]{2}{*}{ Standalone } & & & -0.00294 & & \\
\hline & & & $(0.044)$ & & \\
\hline \multirow[t]{2}{*}{ Standalone $\times$ lockdown } & & & -0.042 & & \\
\hline & & & $(0.105)$ & & \\
\hline \multirow[t]{2}{*}{ New deaths per 100000} & & & & -0.007 & \\
\hline & & & & $(0.006)$ & \\
\hline \multirow[t]{2}{*}{ New log cases per 100000} & & & & & -0.014 \\
\hline & & & & & $(0.027)$ \\
\hline Observations & 175 & 170 & 175 & 175 & 175 \\
\hline Adjusted R ${ }^{2}$ & 0.325 & 0.322 & 0.101 & 0.326 & 0.323 \\
\hline Units & 35 & 35 & 35 & 35 & 35 \\
\hline Conurbations & 18 & 18 & 18 & 18 & 18 \\
\hline Standalone municipalities & 17 & 17 & 17 & 17 & 17 \\
\hline
\end{tabular}

VAT - value-added tax

*All specifications have both geography (conurbation, standalone municipalities) and time fixed-effects. Robust standard errors in parenthesis. Localized lockdowns at the conurbation level are aggregated and weighted by total 2018 VAT. COVID-19 deaths and cases are calculated at the conurbation level. $\uparrow P<0.10$.

$\ddagger P<0.05$.

$\S P<0.01$.

municipalities. The results show that one month of lockdown results in a significant decrease of $24 \%$ of VAT collection $(\beta=-0.243 ; 95 \% C I=-0.370,-0.117 ; P<0.001)$. We did not find evidence for a differential effect in standalone municipalities. However, the coefficient in Table 3, column 3, was not statistically different from the coefficient in Table 3, columns (1) and (2). 
Last, we examined whether the lockdown effect was different from the perceived threat or risk from COVID-19. In Table 3, columns (4) and (5) show lockdowns were no longer statistically significant at conventional levels ( $P=0.240$ and $P=0.175$, respectively). However, the coefficient's sign was still negative and about the same magnitude as the coefficient in Table 3, columns (7) and (8). The joint significance test for the proportion of the month under lockdown and lagged per capita COVID-19 deaths and incidence was significant $(\mathrm{F}=3.84, \mathrm{P}<0.05 ; \mathrm{F}=2.81, P=0.064$, respectively). Thus, working with data at the conurbation-level instead of the municipality-level makes it harder to disentangle the effect of lockdowns. This difficulty is partly explained by insufficient statistical power and by limited variation in the lockdown variable. The last columns of Table 3 reinforce the advantage of our baseline setting at the municipal level, with more sizable variation in the lockdown (key) variable.

Table S1 in the Online Supplementary Document also shows that our baseline results are robust to controlling for a measure of cell phone-based mobility. However, we also argue that it might be misleading to control for mobility since it is one of the main mediating channels by which lockdown affects economic activity (see Appendix S1 in the Online Supplementary Document for further discussion).

\section{DISCUSSION}

Our results suggest that a full-month lockdown explains a drop in activity of the order of 10-15 percentage points, almost twice the reduction for non-locked down areas. While the expected sign of the effect of lockdowns on economic activity might be obvious, its magnitude is not.

These estimates are large. Our estimates suggest that a three-to-four-month lockdown would reduce economic activity by approximately the same amount that the recession affected the Chilean economy in the (whole) year 2009. During the 2009 Great Recession, GDP declined by 1.1\% instead of growing by 3.7\% [56]. These three to four months only consider the additional effect of lockdowns. If one considered the whole drop in economic activity, the magnitude would be twice as much (in two months under lockdown in 2020, the GDP decline is comparable to the annual decrease in 2009).

Another way of thinking quantitatively about the magnitude and implications of our baseline estimate is in terms of employment. Assuming a standard short-run labour-to-economic activity elasticity of around 0.30.5 , as suggested by an OECD study [40], a one-month lockdown would imply a drop of about $6 \%$ in monthly employment. We estimate this illustrative $6 \%$ fall in monthly employment by multiplying the coefficient of -0.15 in Table 2 by an average short-run labour-to-economic activity elasticity of 0.4 .

It is also useful to contrast our results with the polar case of South Korea, without lockdowns. Aum et al. found that a one-per-thousand increase in the infection rate was associated with an employment loss of 2 to 3 percent. Extrapolating this result to the United States and the United Kingdom, which had large-scale lockdowns, Aum et al. [30] argue that only half of the 5 to 6 percent drop in job losses in these Western economies might be attributable to lockdowns. The rest would be from social panic, some other large-scale non-pharmaceutical intervention, such as school closures, or demand effects. This similar effect of areas with and without lockdown seems consistent with our findings. Importantly, we obtained our results from a direct test in the same sample, instead of extrapolating across countries. The relatively large effect of lockdowns has not yet been found empirically in the United States. For instance, Bartik et al. found that the relative impact of lockdowns was smaller, explaining 1/6 of the total fall during the COVID-19 pandemic. Our results show that lockdowns explain half of the effect, both in the raw time series (Figure 3) and in the main regressions (Table 2). Thus, we offer a qualification to Brzezinksi et al. [57], who found that not imposing lockdowns barely improves economic performance while drastically increasing medical costs. This baseline drop probably includes threat or risk perception and includes other economic channels, like lower spending [31].

Epidemiological evidence suggests that localized lockdowns reduce epidemic growth [47], but their effectiveness is affected by spill overs from neighbouring areas where there is economic interdependence, such as in a city [21]. From an epidemiological standpoint, governments may desire to implement localized lockdowns at the city-level, where "buffer" zones exist to minimize transmission networks [34]. We examined localized lockdowns at different scales to understand their relative economic costs, understanding that this is only one portion of the relevant cost-benefit calculation. Our findings suggest no disproportionate economic gains from unlocking a part of the city. Our estimated effects of lockdowns on the economy are unchanged by scale. The plausible channels that mitigate or amplify the economic impact in the case of a widespread vis-à-vis a local lockdown do not seem critical, at least in our study setting, suggesting the convenience of implementing localized lockdowns at the city or commuting area levels, if epidemiologically appropriate. 
Economic problems could also feedback into health through several channels. For instance, a drop in economic activity of 10-15 percentage points is relevant because lockdowns can affect government budgets, even in the long term. For example, Frenier et al. [58] argue that several states in the USA will probably face severe budget deficits from tax revenue reductions from the pandemic. Further, an economic downturn may prompt many deaths of despair and mental illness from unemployment and isolation [59].

Our estimates have limitations. First, we used a tax payment as a proxy for economic activity. Nonetheless, we also have VAT and survey-based employment at the regional level in Chile. We found a statistically significant elasticity of 0.3 between the drop in VAT and the decline in total employment (including self-employed), consistent with short-run output-employment elasticities in the literature (34). Another limitation is that informal economic activity is, by its very nature, not directly captured in our measures of VAT. However, compared to Latin America (53\%), Chile has relatively low levels of informality (30\%) [60], which have declined in the past decade [61]. Still, many households depend on daily wages from informal employment, which has critically affected their capacity to comply with some non-pharmaceutical interventions such as localized lockdowns $[48,49]$. The World Bank has recently underscored the pandemic's adverse effects on informal employment and businesses, which are harder to reach through policy instruments such as subsidies or payment deferrals [27]. We lack data on informal activity during the pandemic. However, we have some indirect evidence of the pandemic's large economic effects on informal activity through data from informal settlements in Chile. A nationally representative panel survey of informal settlements showed that about $75 \%$ of individuals had lost more than half their income since the pandemic began [62], a substantially larger decline in income compared to the general population. These data suggest that our estimates of the effects of COVID-19 on the Chilean economy may be conservative.

Our study may also have other confounders. For instance, the government gave some leeway on when to pay taxes, and we could only examine monthly-level observations. Nevertheless, there are no apparent reasons why these confounders may interact with lockdowns. These confounders may have also introduced measurement error in our tax measures. This measurement error would have increased our standard errors, making it more difficult to get statistical significance. Nevertheless, we did get relevant and robust estimates across various specifications, which mitigates these concerns.

\section{CONCLUSIONS}

We used a rich data set of localized lockdowns in Chile to measure their effect on economic activity. We find sizeable impacts of lockdowns, doubling the drop in economic activity compared to non-treated municipalities, and robust to several model specifications and controls. As many countries are beginning to reopen and ease mobility restrictions, localized lockdowns can be a critical tool to control COVID-19 resurgence while minimizing economic impact. We found no evidence that localized lockdowns generate a proportionally larger or smaller effect in the economy when applied to areas of different sizes. Critically, our results suggest that epidemiological criteria should guide decisions about the optimal size of lockdown areas since the proportional effects of lockdowns on the economy seem to be unchanged by the geographic scale of the restrictions.

Acknowledgments: We thank Sebastian Piña (Universidad de Chile) for excellent research assistance, Paula Aguirre (Pontificia Universidad Católica de Chile) for help with Figure 1, and the Servicio de Impuestos Internos (Chilean Tax Authority) for the local Value-added-tax data. Our research uses public administrative data collected by the Chilean government. Data were aggregated at the municipality level, and subjects cannot be identified directly or through identifiers. It is considered exempt by the Comite Ético Científico of Pontificia Universidad Católica de Chile. The data on VAT used for this study is available from the corresponding author upon reasonable request and with permission of the tax authority.

Funding information: This research was supported by the Agencia Nacional de Investigación y Desarrollo (ANID) Project ANID-COVID-0377 to KA and RW; ANID Millennium Science Initiative Program MICROB-R [NCN17_081] and MLIV [NCS17_062] to EU; Fondo Nacional de Desarrollo Científico y Tecnológico (FONDECYT) [Grant 11191206] to RW; Centre for Sustainable Urban Development (CEDEUS), ANID Fondo de Financiamiento de Centros de Investigación en Áreas Prioritarias (FONDAP) [Grant 15110020] to KA; and Research Center for Integrated Disaster Risk Management (CIGIDEN), ANID FONDAP [Grant 15110017] to RV and EU.

Authorship contributions: KA, EU, RV and RW contributed to the design and implementation of the research, to the analysis of the results and to the writing of the manuscript.

Competing interests: The authors completed the Unified Competing Interest form at www.icmje.org/coi_disclosure.pdf (available upon request from the corresponding author), and declare no conflicts of interest.

\section{Additional material}

Online Supplementary Document 
1 Ledford H, Cyranoski D, Noorden RV. The UK has approved a COVID vaccine - here's what scientists now want to know. Nature. 2020;588:205-6. Medline:33288887 doi:10.1038/d41586-020-03441-8

2 Tanne JH. Covid-19: FDA panel votes to authorise Pfizer BioNTech vaccine. BMJ. 2020;371:m4799. Medline:33310748 doi:10.1136/bmj.m4799

3 Hsiang S, Allen D, Annan-Phan S, Bell K, Bolliger I, Chong T, et al. The effect of large-scale anti-contagion policies on the COVID-19 pandemic. Nature. 2020;584:262-7. Medline:32512578 doi:10.1038/s41586-020-2404-8

4 Walker PGT, Whittaker C, Watson OJ, Baguelin M, Winskill P, Hamlet A, et al. The impact of COVID-19 and strategies for mitigation and suppression in low- and middle-income countries. Science. 2020;369:413-22. Medline:32532802

5 Wiersinga WJ, Rhodes A, Cheng AC, Peacock SJ, Prescott HC. Pathophysiology, Transmission, Diagnosis, and Treatment of Coronavirus Disease 2019 (COVID-19): A Review. JAMA. 2020;324:782-93. Medline:32648899 doi:10.1001/ jama.2020.12839

6 Li Y, Campbell H, Kulkarni D, Harpur A, Nundy M, Wang X, et al. The temporal association of introducing and lifting non-pharmaceutical interventions with the time-varying reproduction number (R) of SARS-CoV-2: a modelling study across 131 countries. Lancet Infect Dis. 2020. Online ahead of print. doi:10.1016/S1473-3099(20)30785-4

7 Flaxman S, Mishra S, Gandy A, Unwin HJT, Mellan TA, Coupland H, et al. Estimating the effects of non-pharmaceutical interventions on COVID-19 in Europe. Nature. 2020;584:257-61. Medline:32512579 doi:10.1038/s41586-020-2405-7

8 Davies NG, Kucharski AJ, Eggo RM, Gimma A, Edmunds WJ, Jombart T, et al. Effects of non-pharmaceutical interventions on COVID-19 cases, deaths, and demand for hospital services in the UK: a modelling study. Lancet Public Health. 2020;5:e37585. Medline:32502389 doi:10.1016/S2468-2667(20)30133-X

9 Lavezzo E, Franchin E, Ciavarella C, Cuomo-Dannenburg G, Barzon L, Del Vecchio C, et al. Suppression of a SARS-CoV-2 outbreak in the Italian municipality of Vo'. Nature. 2020;584:425-9. Medline:32604404 doi:10.1038/s41586-020-2488-1

10 Hao X, Cheng S, Wu D, Wu T, Lin X, Wang C. Reconstruction of the full transmission dynamics of COVID-19 in Wuhan. Nature. 2020;584:420-4. Medline:32674112 doi:10.1038/s41586-020-2554-8

11 Cousins S. New Zealand eliminates COVID-19. Lancet. 2020;395:1474. Medline:32386582 doi:10.1016/S01406736(20)31097-7

12 Cowling BJ, Ali ST, Ng TWY, Tsang TK, Li JCM, Fong MW, et al. Impact assessment of non-pharmaceutical interventions against coronavirus disease 2019 and influenza in Hong Kong: an observational study. Lancet Public Health. 2020;5:e27988. Medline:32311320 doi:10.1016/S2468-2667(20)30090-6

13 Pan A, Liu L, Wang C, Guo H, Hao X, Wang Q, et al. Association of Public Health Interventions With the Epidemiology of the COVID-19 Outbreak in Wuhan, China. JAMA. 2020;323:1915-23. Medline:32275295 doi:10.1001/jama.2020.6130

14 Lai S, Ruktanonchai N, Zhou L, Prosper O, Luo W, Floyd J, et al. Effect of non-pharmaceutical interventions to contain COVID-19 in China. Nature. 2020;585:410-3. Medline:32365354 doi:10.1038/s41586-020-2293-x

15 Rudan I. Answering 20 more questions on COVID-19 (March-April 2020). J Glob Health. 2020;10:020102. Medline:33110501 doi:10.7189/jogh.10.020102

16 Shimizu K, Wharton G, Sakamoto H, Mossialos E. Resurgence of covid-19 in Japan. BMJ. 2020;370:m3221. Medline:32816821 doi:10.1136/bmj.m3221

17 Ruktanonchai NW, Floyd J, Lai S, Ruktanonchai CW, Sadilek A, Rente-Lourenco P, et al. Assessing the impact of coordinated COVID-19 exit strategies across Europe. Science. 2020;369:1465-70. Medline:32680881 doi:10.1126/science.abc5096

18 Wise J. Covid-19: Risk of second wave is very real, say researchers. BMJ. 2020;369:m2294. Medline:32518177 doi:10.1136/ bmj.m2294

19 IHME COVID-19 Forecasting Team. Modeling COVID-19 scenarios for the United States. Nat Med. 2020. Online ahead of print.

20 Kissler SM, Tedijanto C, Goldstein E, Grad YH, Lipsitch M. Projecting the transmission dynamics of SARS-CoV-2 through the postpandemic period. Science. 2020;368:860-8. Medline:32291278 doi:10.1126/science.abb5793

$21 \mathrm{Li}$ Y, Undurraga EA, Zubizarreta JR. Effectiveness of Localized Lockdowns in the SARS-CoV-2 Pandemic. medRxiv. 2020:2020.08.25.20182071.

22 Shea K, Runge MC, Pannell D, Probert WJM, Li S-L, Tildesley M, et al. Harnessing multiple models for outbreak management. Science. 2020;368:577-9. Medline:32381703 doi:10.1126/science.abb9934

23 Karatayev VA, Anand M, Bauch CT. Local lockdowns outperform global lockdown on the far side of the COVID-19 epidemic curve. Proc Natl Acad Sci U S A. 2020;117:24575-80. Medline:32887803 doi:10.1073/pnas.2014385117

24 Britton T, Ball F, Trapman P. A mathematical model reveals the influence of population heterogeneity on herd immunity to SARS-CoV-2. Science. 2020;369:846. Medline:32576668 doi:10.1126/science.abc6810

25 Firth JA, Hellewell J, Klepac P, Kissler S, Kucharski AJ, Spurgin LG. Using a real-world network to model localized COVID-19 control strategies. Nat Med. 2020;26:1616-22. Medline:32770169 doi:10.1038/s41591-020-1036-8

26 Rainisch G, Undurraga EA, Chowell G. A dynamic modeling tool for estimating healthcare demand from the COVID19 epidemic and evaluating population-wide interventions. Int J Infect Dis. 2020;96:376-83. Medline:32425631 doi:10.1016/j. ijid.2020.05.043

27 World Bank. The Economy in the Time of CoVID-19. 2020. Available: https://bit.ly/35B2r3y. Accessed: 21 April 2020.

28 Baek C, McCrory PB, Messer T, Mui P. Unemployment effects of stay-at-home orders: Evidence from high frequency claims data. The Review of Economics and Statistics. 2020. doi:10.1162/rest_a_00996

29 Lozano-Rojas F, Jiang X, Montenovo L, Simon KI, Weinberg BA, Wing C. Is the cure worse than the problem itself? immediate labor market effects of covid-19 case rates and school closures in the US. National Bureau of Economic Research. 2020;WP27172:1-17. 
30 Aum S, Lee SYT, Shin Y. COVID-19 Doesn't Need Lockdowns to Destroy Jobs: The Effect of Local Outbreaks in Korea. National Bureau of Economic Research. 2020:w27264:1-19.

31 Gupta S, Montenovo L, Nguyen TD, Rojas FL, Schmutte IM, Simon KI, et al. Effects of social distancing policy on labor market outcomes. National Bureau of Economic Research. 2020:WP27280:1-49.

32 Pfefferbaum B, North CS. Mental Health and the Covid-19 Pandemic. N Engl J Med. 2020;383:510-2. Medline:32283003 doi:10.1056/NEJMp2008017

33 de Girolamo G, Cerveri G, Clerici M, Monzani E, Spinogatti F, Starace F, et al. Mental Health in the Coronavirus Disease 2019 Emergency_The Italian Response. JAMA Psychiatry. 2020;77:974-6. Medline:32352480 doi:10.1001/jamapsychiatry.2020.1276

34 Chowdhury R, Luhar S, Khan N, Choudhury SR, Matin I, Franco OH. Long-term strategies to control COVID-19 in low and middle-income countries: an options overview of community-based, non-pharmacological interventions. Eur J Epidemiol. 2020;35:743-8. Medline:32656618 doi:10.1007/s10654-020-00660-1

35 Mahase E. Covid-19: How does local lockdown work, and is it effective? BMJ. 2020;370:m2679. Medline:32620558 doi:10.1136/bmj.m2679

36 Bartik AW, Bertrand M, Lin F, Rothstein J, Unrath M. Measuring the labor market at the onset of the COVID-19 crisis. National Bureau of Economic Research, 2020;WP27613:1-53.

37 Forsythe E, Kahn LB, Lange F, Wiczer D. Labor Demand in the time of COVID-19: Evidence from vacancy postings and UI claims. J Public Econ. 2020;189:104238. Medline:32834178 doi:10.1016/j.jpubeco.2020.104238

38 Goolsbee A, Syverson C. Fear, lockdown, and diversion: Comparing drivers of pandemic economic decline 2020. National Bureau of Economic Research, 2020;WP27432:1-25.

39 Coibion O, Gorodnichenko Y, Weber M. The cost of the covid-19 crisis: Lockdowns, macroeconomic expectations, and consumer spending. National Bureau of Economic Research, 2020;WP27141:1-51.

40 Görg H, Hornok C, Montagna C, Onwordi G. Employment to output elasticities \& reforms towards flexicurity: Evidence from OECD countries. IZA Discussion Paper. 2018;IZADP12004:1-38.

41 Taylor L. How South America became the new centre of the coronavirus pandemic. New Sci. 2020.

42 Dong E, Du H, Gardner L. An interactive web-based dashboard to track COVID-19 in real time. Lancet Infect Dis. 2020;20:5344. Medline:32087114 doi:10.1016/S1473-3099(20)30120-1

43 de Souza WM, Buss LF, Candido DS, Carrera J-P, Li S, Zarebski AE, et al. Epidemiological and clinical characteristics of the COVID-19 epidemic in Brazil. Nat Hum Behav. 2020;4:856-65. Medline:32737472 doi:10.1038/s41562-020-0928-4

44 Moreira RM, Montoya ACV, Araujo SLS, Trindade RA, da Cunha Oliveira D, de Oliveira Marinho G. How prepared is Brazil to tackle the COVID-19 disease? J Glob Health. 2020;10:020321. Medline:33110523 doi:10.7189/jogh.10.020321

45 Taylor L. How Latin America is fighting covid-19, for better and worse. BMJ. 2020;370:m3319. Medline:32873574 doi:10.1136/ bmj.m3319

46 Ministerio de Salud. Plan de acción por coronavirus. 2020. Available: https://www.gob.cl/coronavirus/plandeaccion/. Accessed: 10 October 2020.

47 Cuadrado C, Monsalves MJ, Gajardo J, Bertoglia MP, Najera M, Alfaro T, et al. Impact of small-area lockdowns for the control of the COVID-19 pandemic. medRxiv. 2020:2020.05.05.20092106. doi:10.1101/2020.05.05.20092106

48 Bennett M. All things equal? Heterogeneity in policy effectiveness against COVID-19 spread in chile. World Dev. 2021;137:105208. Medline:32994662 doi:10.1016/j.worlddev.2020.105208

49 Gil M, Undurraga EA. COVID-19 has exposed how 'the other half (still) lives. Bull Lat Am Res. 2020;39:28-34. doi:10.1111/blar.13175

50 Aguirre P, Asahi K, Díaz-Rioseco D, Riveros I, Valdés R. Medium-run Local Economic Effects of a Major Earthquake. Unpublished Manuscript, Pontificia Universidad Católica de Chile. 2020.

51 Instituto Nacional de Estadísticas. Estimaciones y proyecciones de la población de Chile 1992-2050. 2017. Available: https:// www.censo2017.cl/. Accessed: 2 April 2020.

52 Ministerio de Salud. Cifras Oficiales COVID-19. 2020. Available: https://www.gob.cl/coronavirus/cifrasoficiales/. Accessed: 30 October 2020.

53 Ministerio de Ciencia T. Conocimiento, e Innovación, Base de datos CoVID-19. 2020. Available: http://www.minciencia.gob. cl/covid19. Accessed: 29 September 2020.

54 Bravo L, Ferres L. The IM (Mobility Index) dataset. Data Science Institute Universidad del Desarrollo. Santiago, Chile, 2020.

55 Bavel JJV, Baicker K, Boggio PS, Capraro V, Cichocka A, Cikara M, et al. Using social and behavioural science to support COVID-19 pandemic response. Nat Hum Behav. 2020;4:460-71. Medline:32355299 doi:10.1038/s41562-020-0884-z

56 Banco Central de Chile. Cuentas Nacionales 2003-2009, Cuadro 1.3. 2010. Available: https://bit.ly/3obaYm9. Accessed: 1 September 2020

57 Brzezinski A, Kecht V, Van Dijcke D. The Cost of Staying Open: Voluntary Social Distancing and Lockdowns in the US. Economics Series Working Papers Oxford. 2020;910:1-39.

58 Frenier C, Nikpay SS, Golberstein E. COVID-19 Has Increased Medicaid Enrollment, But Short-Term Enrollment Changes Are Unrelated To Job Losses. Health Aff (Millwood). 2020;39:1822-31. Medline:32757955 doi:10.1377/hlthaff.2020.00900

59 Case A, Deaton A. Deaths of Despair and the Future of Capitalism: Princeton University Press; 2020.

60 Levy-Yeyati E, Valdés R. COVID-19 in Latin America: How is it different than in advanced economies? In: Djankov S, Panizza U, editors. COVID-19 in Developing Economies CEPR Press VoxEU.org eBook; 2020.

61 International Labour Organization. Recent experiences of formalization in Latin America and the Caribbean. 2014. Available: https://bit.ly/2IJ2m6V. Accessed: 11 December 2020.

62 Gil D, Undurraga EA, Valenzuela E, Bowen S, Palacios P. Efectos socioeconómicos y percepción de riesgo del CoVID-19 en campamentos y población vulnerable en Chile, mayo-septiembre 2020. 2020. Available: https://bit.ly/3b3aWsI. Accessed: 3 December 2020. 